“C 2017 IEEE. Personal use of this material is permitted. Permission from IEEE must be obtained for all other uses, in any current or future media, including reprinting/republishing this material for advertising or promotional purposes, creating new collective works, for resale or redistribution to servers or lists, or reuse of any copyrighted component of this work in other works." 


\title{
Input Current Ripple Reduction and High Efficiency for PEM Fuel Cell Power Conditioning System
}

\author{
Yuedong Zhan ${ }^{1 *}$, Youguang $\mathrm{Guo}^{2}$, Jianguo $\mathrm{Zhu}^{2}$, and $\mathrm{Li} \mathrm{Li}^{1}$ \\ ${ }^{1}$ Department of Automation, Kunming University of Science and Technology, Kunming, China \\ ${ }^{2}$ School of Electrical, Mechanical and Mechatronic Systems, University of Technology Sydney, Australia \\ *E-mail: ydzhan@163.com
}

\begin{abstract}
To solve the issues of the open-loop control accuracy in a proton exchange membrane (PEM) fuel cell power conditioning system (PCS) with active clamp push-pull DC/DC converter for input current ripple reduction, a novel closed-loop digital-controlled method is proposed. The proposed PEM fuel cell PCS consists of a high-efficiency highstep-up current-fed resonant push-pull DC/DC converter and a half-bridge inverter. A fully digital-controlled strategy in the active-clamped circuit is employed to reduce the voltage spike and low frequency current ripple (LFCR) on the power switches for improving the lifespan of PEM fuel cell and raising the system reliability. By using the closed-loop current ripple reduction control, the LFCR is further reduced. A 300 $\mathrm{W}$ prototype is implemented and tested. Experimental results show that the minimum efficiency at full load is about $94.8 \%$ and the ripple current is less than $1.2 \%$ of the rated input current.
\end{abstract}

Index Terms--Input current ripple reduction, Power conditioning system, Proton exchange membrane (PEM) fuel cell.

\section{INTRODUCTION}

Because the proton exchange membrane (PEM) fuel cell based on hydrogen has the long continuous run-time, high power density, low operating temperature, and no pollution and noise, it is much suitable for a reliable power sources in the power conditioning system (PCS) applications. For instance, for an uninterruptible power supply (UPS) system, using the DC/DC converter, the low PEM fuel cell voltage of $36 \mathrm{~V}$ is boosted to $\pm 380 \mathrm{~V}$ for the DC/AC inverter, as shown in Fig. 1.

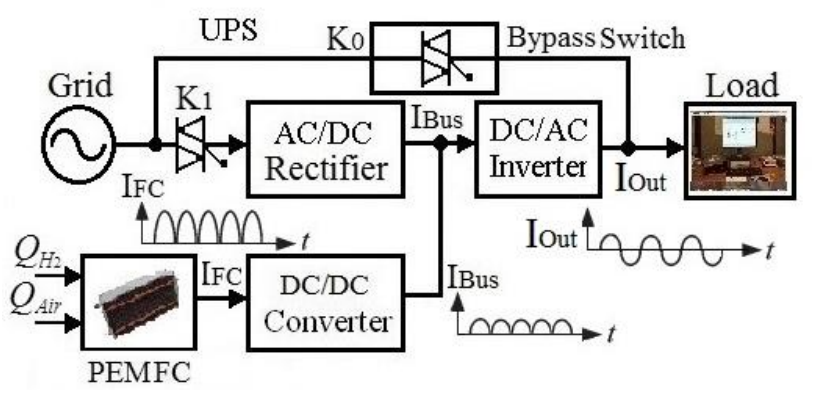

This work was supported by the National Nature Science Foundation of China under Grant 51667012.
Fig. 1. Low frequency current ripples (LFCRs) in UPS system.

The PEM fuel cell power generation systems are low voltage and high current devices, and hence their low frequency current ripple (LFCR) is a major issue for the DC/DC converter design [1, 2]. The input LFCR must be limited to be within $5 \%$ of normal rated value to ensure the PEM fuel cell operation satisfactory [3]. For the first time, the USA National Energy Technology Laboratory has given the limits of the LFCR for PEM fuel cell, which suggests that the $100 \mathrm{~Hz}$ or $120 \mathrm{~Hz}$ ripple should be lower than $15 \%$ from $10 \%$ to $100 \%$ load, not to exceed 0.6 A for lighter loads, and the $50 \mathrm{~Hz}$ or $60 \mathrm{~Hz}$ ripple should be lower than $10 \%$ from $10 \%$ to $100 \%$ loads, not to exceed 0.4 A for lighter loads [4]. Therefore, to control the high current, to limit the LFCR within the mentioned value, i.e. 5\%, and to prolong the lifetime of $\mathrm{FC}$, three main types of ripple current mitigation strategies have been proposed as follows: (1) Passive compensation approaches, (2) Active compensation approaches, and (3) Passive and active comprehensive compensation methods [5].

In the input LFCR mitigation strategies, the latest research results are summarized as follows. Sha, et al. [6] proposed a novel current fed hybrid dual active bridge DC/DC converter, in which the high frequency input current ripple can be reduced to minimum value because the input side switches were always switched at $50 \%$ duty cycles in spite of the PEM fuel cell voltage and the load variation. Notch filter was applied in the voltage feedback path to reduce the input LFCR when interfaced with a single phase inverter load. All of the power devices can achieve zero voltage switching on by the proposed control strategy. García-Vite et al. [7] proposed a DC/DC converter with quadratic voltage gain which can drain the ripple-free current from the source at a selectable duty cycle. Because of these features, the topology proposed herein was of special interest in renewable energy systems which had the low voltage generation sources and were sensitive to current ripple from converters. It discussed the converter's principle of operation, focusing on modeling and design guidelines. 
Abeywardana, et al. [8] proposed a novel current feedback method to mitigate the second harmonic current component at the DC bus, with which the maximum second harmonic ripple amplitudes were $0.172 \mathrm{~A}$ during the transient time and $0.0588 \mathrm{~A}$ in the steady state. However, without the proposed method, the second order harmonic ripple amplitude was 1.482 A. Naik, et al. [9] analyzed the different DC/DC converter topologies, such as the boost converter, multiple device boost converter, multiple phase interleaved boost converters and multiple device multiple phase interleaved boost converters with respect to the current ripple reduction, in which the input ripple currents of different topologies were $2.62 \%, 1.7 \%, 0.006 \%$, and $0.00012 \%$, respectively. Therefore, the topologies and their mitigation control strategies of a PCS in PEM fuel cell generation system can improve the performance and lifetime of fuel cell.

This paper conducts the study on the influence of injected LFCR, generation mechanism of current ripple, and traditional LFCR mitigation methods including the main current ripple reduction approaches and their control strategies in Section 2. Section 3 details the proposed closed-loop digital control strategy of LFCR based on the designed push-pull DC/DC converter. In Section 4, all control functions are implemented fully in software with a digital signal processor (DSP) TMS320F2406 controller, where the PEM fuel cell PCS is realized with the minimal hardware and low cost. Experimental results obtained on a $300 \mathrm{~W}$ prototype show the performance of the proposed PEM fuel cell PCS.

\section{Generation MECHANISM OF LOW FREQUENCY CURRENT RIPPLE}

As shown in Fig. 1, according to the operating principle of half-bridge DC/AC inverter, the final output voltage becomes a frequency of $50 \mathrm{~Hz}$ or $60 \mathrm{~Hz}$ sinusoidal waveform after filtering. The filtered output voltage and current of this inverter are expressed as follows [10].

$$
\begin{gathered}
v_{0}(t)=\sqrt{2} V_{0} \cos (\omega t) \\
i_{0}(t)=\sqrt{2} I_{0} \cos (\omega t+\varphi)
\end{gathered}
$$

where $V_{0}$ and $I_{0}$ are the root mean square (RMS) values of output voltage and output current for the inverter respectively, and $\varphi$ is the phase angle between the voltage and current.

By multiplying (1) and (2), the output power of the inverter is calculated as

$$
P_{0}(t)=v_{0}(t) i_{0}(t)=V_{0} I_{0}[\cos (2 \omega t+\varphi)+\cos \varphi]
$$

Based on the principle of the pulse width modulation (PWM) of DC/DC converter, sinusoidal PWM (SPWM) of $\mathrm{DC} / \mathrm{AC}$ inverter, and the energy conservation law when neglecting the power losses of the converter and inverter in this PCS system, the powers at the PEM fuel cell, DC bus and $\mathrm{AC}$ output should be almost the same.

$$
V_{F C} I_{F C}(t)=V_{B u s} I_{B u s}^{*}(t)=P_{0}(t)
$$

where $I_{B U S}^{*}$ is the filtered current of DC bus, which consists of a pure DC value and a sinusoidal value at twice the fundamental frequency $2 \omega=100 \mathrm{~Hz}$ or $120 \mathrm{~Hz}$. The term $I_{B U S}$ is the inverter input current, which consists of $I_{B U S}^{*}$ and the high frequency values based on the frequency of switching on and off in the DC/AC inverter.

According to (4), there is

$$
I_{\text {Bus }}^{*}(t)=\frac{P_{0}(t)}{V_{\text {Bus }}}=\frac{V_{0} I_{0}}{V_{B u s}}[\cos \varphi+\cos (2 \omega t+\varphi)]
$$

According to (5), the input current to the PCS is the one of the PEM fuel cell, which contains a periodic signal with the frequency $2 \omega$ on average DC bus.

Although the DC bus output has the capacitors, its impedance is not infinite, only the LFCR is charged and discharged through the DC bus capacitors, which contains the AC value with the frequency $2 \omega=100 \mathrm{~Hz}$ or $120 \mathrm{~Hz}$. Hence, the DC bus capacitor voltage can be derived as follows.

$$
\begin{aligned}
v_{B U S}(t) & =V_{B U S}+\frac{1}{C_{B U S}} \int I_{B U S}^{*} d t \\
& =V_{B U S}\left[1+\frac{V_{0} I_{0}}{2 \omega C_{B U S} V_{B U S}^{2}} \sin (2 \omega t+\varphi)\right]
\end{aligned}
$$

When the PEM fuel cell output voltage can be regarded as current controlled voltage source, its current contains 100 $\mathrm{Hz}$ or $120 \mathrm{~Hz}$ ripple value.

$$
I_{F C}(t)=v_{B u s}(t) I_{B u s}^{*}(t) / V_{F C}
$$

Consequently, the LFCR is reflected to the PEM fuel cell stack and produces harmful effects on the fuel cell voltage and current, as shown in Fig. 1.

\section{LOW FREQUENCY CURRENT RIPPLE IMPACTS ON PEM FUEL CELL STACK}

According to the electrochemical impedance spectroscopy (EIS) analysis methods and equivalent circuit model of PEM fuel cell stack, assume that the PEM fuel cell 
must meet the requirement of a linear system, and it is guaranteed by the amplitude of disturbance signals injected into the PEM fuel cell. Therefore, the fluctuation signal can be conducted in either the galvanic-static mode or the potential-static mode [11].

As mentioned above, when the LFCR is injected to the PEM fuel cell stack and produces harmful effects on the fuel cell voltage and current, the output current of the PEM fuel cell stack is defined as

$$
i_{F C}=I_{F C}^{*}+\Delta I_{F C} \sin (\omega t+\theta)
$$

where $I_{F C}^{*}$ indicates the DC current value of the DC/DC converter load (A), $\Delta I_{F C}, \omega$, and $\theta$ stand for the amplitude current value (A), angular frequency ( $\mathrm{rad} / \mathrm{s})$ and phase angle $\left.{ }^{\circ}\right)$ of the perturbation signal (including the LFCR) from DC/DC converter, respectively.

Based on the equivalent circuit model without PEM fuel cell degradation, the total impedance can be defined as

$$
Z(j \omega)=R_{O h m}+\frac{R_{f a} \cdot \frac{1}{j \omega C_{d l a}}}{R_{f a}+\frac{1}{j \omega C_{d l a}}}+\frac{\left(R_{f c}+Z_{W}\right) \cdot \frac{1}{j \omega C_{d l c}}}{\left(R_{f c}+Z_{W}\right)+\frac{1}{j \omega C_{d l c}}}
$$

where $C_{d l a}$ and $C_{d l c}$ are the anode and cathode equivalent capacitor of the double-layer charging effects respectively, $R_{f a}$ and $R_{f c}$ are the anode and cathode activation resistance, $R_{O h m}$ is the Ohmic resistance, and $Z_{W}$ is the porous bounded Warburg impedance, which is given by

$$
Z_{W}=\frac{\sigma_{i}}{\sqrt{\omega}}(1-j) \tan \left(\delta \sqrt{\frac{j \omega}{D_{i}}}\right)
$$

where $\delta$ is the diffusion layer thickness, $D_{i}$ is the diffusion coefficient of species $i\left(\mathrm{H}_{2}, \mathrm{O}_{2}, \mathrm{~N}_{2}\right.$, and $\left.\mathrm{H}_{2} \mathrm{O}\right)$, and $\sigma_{i}$ is the Warburg coefficient for a species $i$ and is defined as

$$
\sigma_{i}=\frac{R T}{\left(n_{i} F\right)^{2} A \sqrt{2}}\left(\frac{1}{c_{i}^{0} \sqrt{D_{i}}}\right)
$$

where $R$ is the universal gas constant $(\mathrm{J} / \mathrm{mol} \cdot \mathrm{K}), T$ is the stack temperature $(\mathrm{K}), F$ is the Faraday's constant $(\mathrm{C} / \mathrm{mol})$, $n_{i}$ is the number of electrons per molecule of a species
$i\left(\mathrm{H}_{2}, \mathrm{O}_{2}, \mathrm{~N}_{2}\right.$, and $\left.\mathrm{H}_{2} \mathrm{O}\right), \mathrm{A}$ is the electrode area $\left(\mathrm{m}^{2}\right)$, and $c_{i}^{0}$ is the bulk concentration of species $i$.

Therefore, from (9), when injecting the LFCR, $Z_{W}=R_{c o n v}=\delta \sigma_{i} \sqrt{\frac{2}{D_{i}}}$, where $R_{c o n v}$ is called as the concentration resistance, reflecting the mass transfer in PEM fuel cell. Then, (9) becomes

$$
\begin{aligned}
Z(j \omega)= & R_{O h m}+\frac{R_{f a} \cdot \frac{1}{j \omega C_{d l a}}}{R_{f a}+\frac{1}{j \omega C_{d l a}}}+\frac{\left(R_{f c}+R_{c o n v}\right) \cdot \frac{1}{j \omega C_{d l c}}}{\left(R_{f c}+R_{c o n v}\right)+\frac{1}{j \omega C_{d l c}}} \\
= & R_{O h m}+\frac{R_{f a}}{1+\omega^{2} \tau_{a}^{2}}+\frac{R_{f c}}{1+\omega^{2} \tau_{c}^{2}} \\
& -j\left[\frac{\omega \tau_{a} \cdot R_{f a}}{1+\omega^{2} \tau_{a}^{2}}+\frac{\omega \tau_{c}\left(R_{f c}+R_{c o n v}\right)}{1+\omega^{2} \tau_{c}^{2}}\right] \\
= & A(\omega) \angle \phi(\omega)
\end{aligned}
$$

where $\tau_{a}=C_{d l a}$ is the anode time constant (s), $\tau_{c}=C_{d l c}\left(R_{f c}+R_{c o n v}\right)$ is the cathode time constant (s), and $A(\omega)$ and $\phi(\omega)$ stand for the amplitude value and the resultant phase shift, respectively.

When the perturbation signal, such as the LFCR, is added to the PEM fuel cell, the output voltage can be defined as

$$
\begin{aligned}
V_{\text {stack }}= & E_{\text {rev }}-N\left(R_{O h m}+R_{f a}+R_{f c}+R_{\text {conv }}\right) I_{F C}^{*} \\
& -N A(\omega) \Delta I_{F C} \sin (\omega t+\theta+\phi)
\end{aligned}
$$

There are perturbation signals, including the LFCR from the PCS, such as the DC/DC converter, compared to that without perturbation signal, the performance of PEM fuel cell stack can be changed because of the AC component in (13), as shown in Fig. 2, which can be identified on two different branches because of the effect of the perturbation signals [12]. 


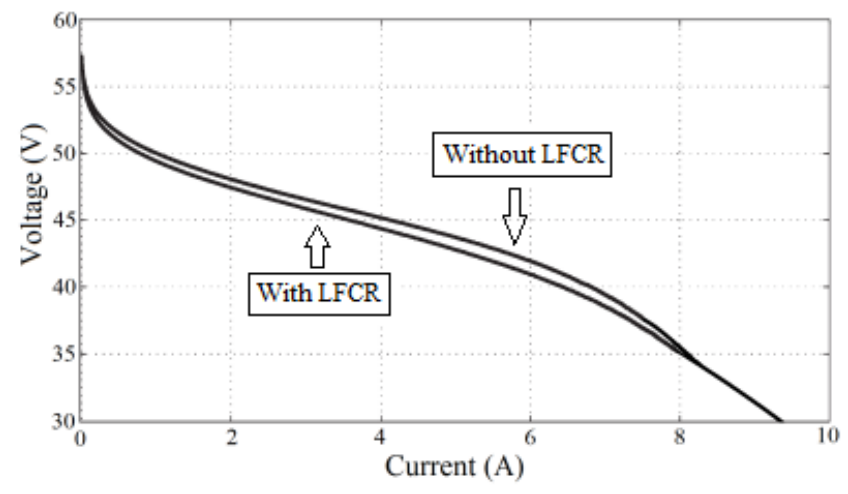

Fig. 2. PEM fuel cell stack efficiency effects of different percentage amplitudes of low frequency ripple current (LFCR).

\section{Design of Closed-loop Digital CURRENT RIPPle CONTROLLER}

In this paper, to reduce the LFCR without increasing the size and cost in the PCS, the push-pull DC/DC converter with active clamp circuit is designed as shown in Fig. 3. In the figure, the switches $\mathrm{S} 1$ and $\mathrm{S} 2$ operate with shift in phase by $T / 2$ and the same duty ratio $D$. The duty ratio must be smaller than 0.5 . When switch $\mathrm{S} 1$ is on, diode D1 and D4 conduct and diode D2 and D3 are off. Diode states are reversed when switch $\mathrm{S} 2$ is on. When both controllable switches are off, the diodes are on and share equally the filter inductor current. The DC voltage transfer function of the push-pull DC/DC converter under the condition of the continuous current is

$$
\frac{V_{B U S}}{V_{F C}}=\frac{2 n}{1-D_{c}}
$$

where $\mathrm{n}=\mathrm{N}_{2} / \mathrm{N}_{1}$, and $D_{c}$ is the control output duty ratio to regulate the DC bus voltage based on the feedback bus voltage without the active clamp circuits.

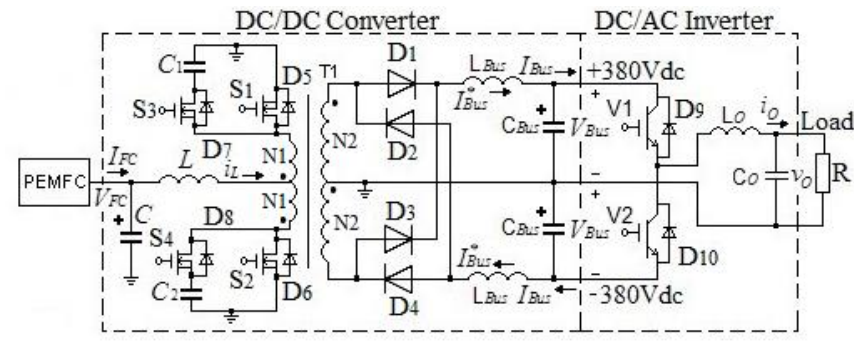

Fig. 3. Push-pull DC/DC converter with active clamp circuits designed in a PCS.

The maximum power point tracking (MPPT) control with a perturbed duty ratio $D_{p}$ is employed to simply reduce the input ripple current of PEM fuel cell, as shown in Fig. 4, which is given by

$$
D_{p}=k_{p}\left(I_{F C}-i_{F C}\right)
$$

where $k_{p}$ is the proportional control gain.

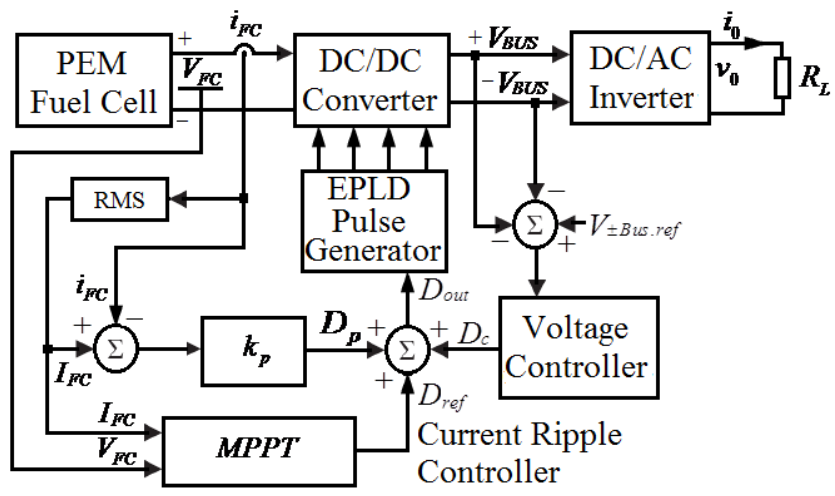

Fig. 4. Block diagram of the proposed push-pull DC/DC converter with active clamp circuits using a DSP computer.

Based on the designed push-pull DC/DC converter with active clamp circuit, a PWM voltage controller and a current ripple reduction controller are employed to regulate the output voltage $\pm V_{B u s}$ and the input current ripple $I_{F C}$ by adjusting the total duty ratio $D_{\text {out }}$, which is

$$
\frac{v_{B U S}(t)}{V_{F C}}=\frac{2 n}{1-D_{\text {out }}}=\frac{2 n}{1-\left(D_{c}+D_{r}\right)}
$$

where $D_{r}$ is a ripple cancellation duty ratio for current ripple reduction. Eq. (16) can be rewritten as

$$
D_{r}=\left(1-D_{c}\right)-2 n \cdot \frac{V_{F C}}{v_{B U S}(t)}
$$

Substituting (6) and (14) into (17), there is

$$
D_{r}=\frac{2 n V_{F C}}{V_{B U S}} \cdot \frac{\frac{V_{0} I_{0} \sin (2 \omega t+\varphi)}{2 \omega C_{B U S} V_{B U S}^{2}}}{1+\frac{V_{0} I_{0} \sin (2 \omega t+\varphi)}{2 \omega C_{B U S} V_{B U S}^{2}}}
$$

According to the analysis of (18), it is used as the closedloop digital-controlled, as shown in Fig. 5, and the best control performances could be obtained because of the digital-controlled DSP controller. The control process could be released easily and programmed by software only. Therefore, there are not additional current ripple compensation component and circuit [13]. 


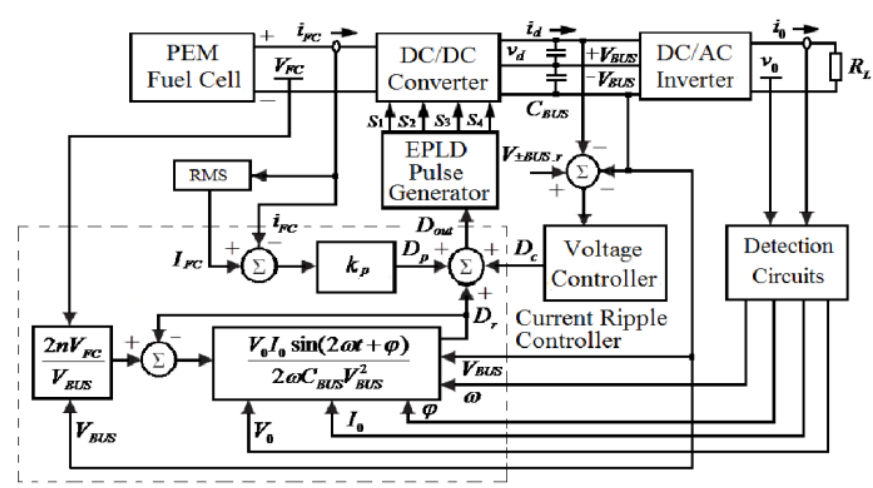

Fig. 5. Block diagram of the proposed closed-loop digital-controlled pushpull DC/DC converter with active clamp circuits.

\section{EXPERIMENTAL SETUP AND RESULTS}

The experimental setup consists of an UPS system, PEM fuel cell generating and test system, lead-acid batteries and a data-acquisition system, which are multifunction I/O devices NI6036E, analog voltage output devices NI6713, parallel digital I/O interface PCI-6503 and analog multiplexer with temperature sensor AMUX-64T. The UPS system with backup PEM fuel cell and battery provides the AC power source and controls the linear loads (e.g. lamp box) and nonlinear loads (i.e. PC), while the dataacquisition system measures and records the required information. In the PEM fuel cell generating and test system, both hydrogen and air are regulated by mass flow controllers (type: F-201C-GAS-22V and F-112AC-GAS$22 \mathrm{~V}$, Bronkhorst). Concerning the application of the PEM fuel cell system in UPS system, the option to humidify the hydrogen is not used. The temperature and humidity of air and hydrogen can be measured at inlet by the hydrotransmitter (type: HD2008TV1, Delta OHM) as well as the pressure transmitter (type: AUS EX 1354X, Burkert) between the inlets of cathode and anode. The output of the UPS is connected to a lamp load that is used in a constant voltage mode. All physical parameters such as currents and voltages of the UPS, PEM fuel cell stack and battery, gas mass flow of the reactants, pressure drop in the flow fields, relative humidity and temperatures of air and hydrogen are recorded with the data-acquisition system [14]-[16].

The PEM fuel cell PCS is designed and experiments are carried out to verify the theoretical analysis. The major components of the prototype used for experiments are presented above. The overall system is implemented fully in software using a digital signal processor TMS320F2406 controller. Voltage and current signals are measured by using a LA55-P and a LV25-P.

Fig. 6 shows the current and voltage waveforms of the PEM fuel cell without any input current ripple reduction control circuits in this PCS system. A large current ripple of the double grid frequency $(100 \mathrm{~Hz})$ exists. The average input current value $I_{F C a v e}$ is $8.218 \mathrm{~A}$, the peak-to-peak current ripple value $I_{F C p p}$ is $2.0 \mathrm{~A}$, and the current ripple percentage $(\mathrm{CR} \%)$ can be determined by

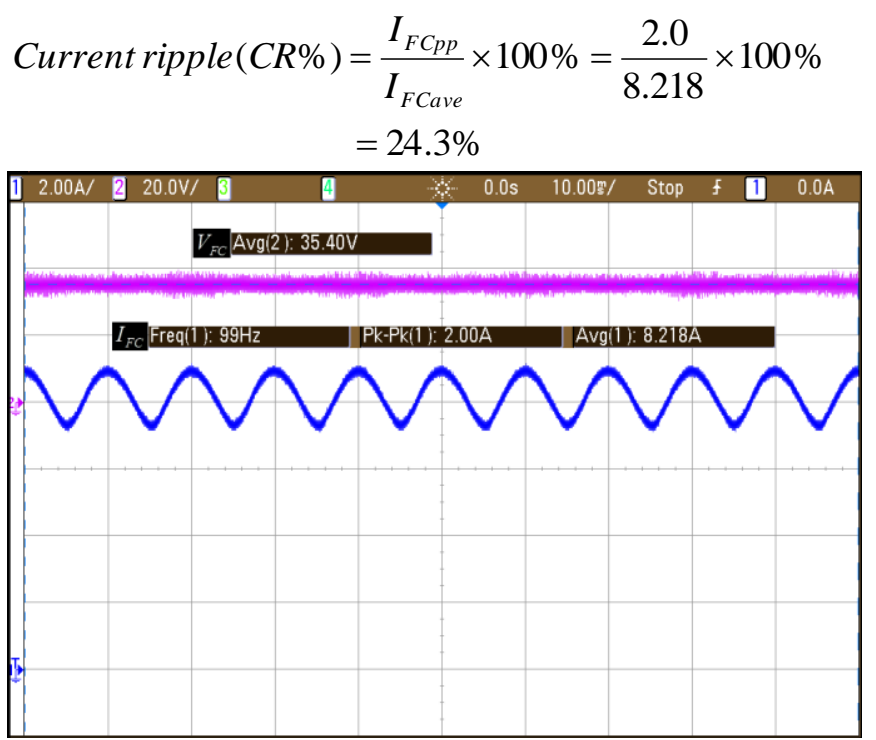

Fig. 6. Input current and voltage waveforms without input current ripple reduction circuits in the PCS system.

Using the proposed control strategy in the active clamp circuits for LFCR reduction, the average input current value $I_{F \text { Cave }}$ is $8.198 \mathrm{~A}$, the peak-to-peak current ripple value $I_{F C p p}$ is $0.098 \mathrm{~A}$, and not only the current ripple percentage of the PEM fuel cell can be reduced to about $1.2 \%$, but also the voltage ripple values can be reduced to about $4.8 \%$, as depicted in Fig. 7. Therefore, the closed-loop digital controller with active clamp circuits could reduce the input current ripple effectively.

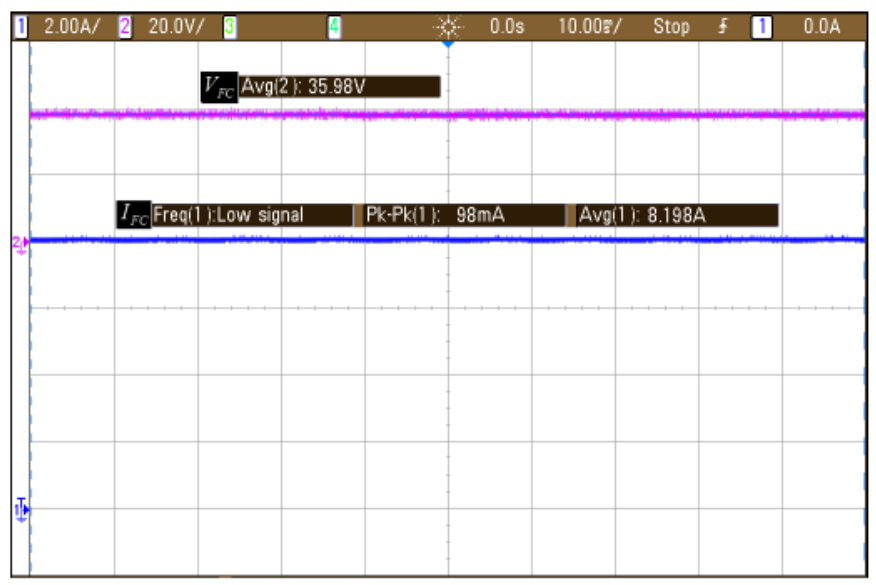

Fig. 7. Input current and voltage waveforms with the proposed closed-loop digital controller push-pull DC/DC converter with active clamp circuits.

Fig. 8 illustrates the PEM fuel cell stack efficiency as a function of current ripple frequency of $50 \mathrm{~Hz}$ to $400 \mathrm{~Hz}$ and current ripple amplitudes of $9.9 \%$ (when using a type of passive compensation method in PCS), and $24.3 \%$ (without 
any compensation methods in PCS) of the rated load (about $8.20 \mathrm{~A}$ ). As expected, the curves show that the efficiency of PEM fuel cell stack decreases when the current ripple amplitude increases, while an increase in the current ripple frequency helps to increase the efficiency, and reduce hydrogen fuel consumption. Therefore, the current ripples at high frequency, such as DC/DC converter switching frequency, which is greatly weakened by the input capacitor, have little or no effect on PEM fuel cell efficiency.

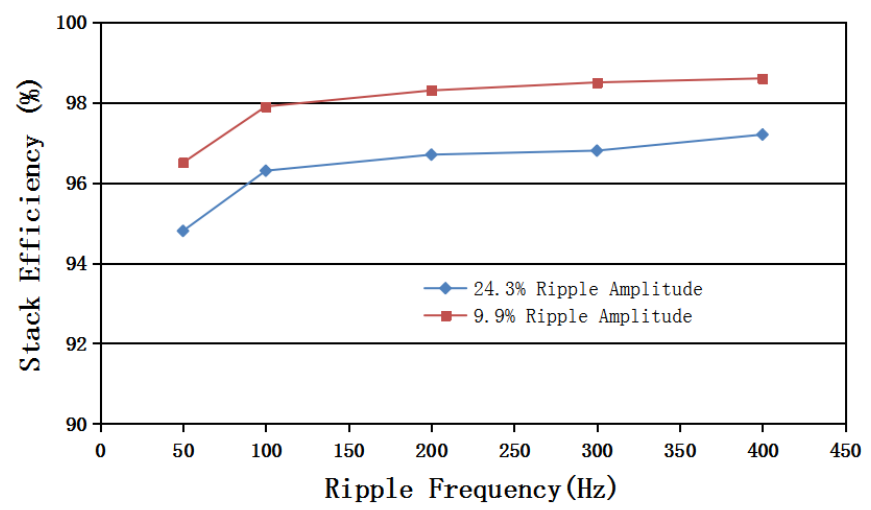

Fig. 8. Effects of different percentage amplitudes of low frequency ripple current (LFCR) on PEM fuel cell stack efficiency.

\section{CONCLUSION}

The generation mechanism and performance effects of injected LFCR on the PEM fuel cell for a PCS are analyzed in this paper. Firstly, the generation principle of input current ripple, the performance and lifetime effects of LFCR on PEM fuel cell are analyzed and validated. Then, the different current ripple reduction approaches and control strategies are reviewed. Finally, a closed-loop digital control method is designed comparing with the traditional compensation controller, and open-loop digital controller in push-pull DC/DC converter with active clamp circuits. The experimental results indicate that the proposed closed-loop digital control method is better than the traditional method for reducing the input LFCR, and the former is of less cost and smaller size. The efficiency of input voltage at full load in $30 \mathrm{~V} @ 8 \mathrm{~A}$ is about $94.8 \%$ and the ripple current is less than $1.2 \%$ of the rated input current without additional ripple compensation component and circuit.

\section{REFERENCES}

[1] C.R. Liu and J.S. Lai, "Low frequency current ripple reduction technique with active control in a fuel cell power system with inverter load," IEEE Trans. Power Electron., vol. 22, no. 4, pp. 1429-1436, 2007.

[2] S.K. Mazumder, et al., "Solid-oxide-fuel-cell performance and durability: resolution of the effects of power-conditioning systems and application loads," IEEE Trans. Power Electron., vol. 19, no. 5, pp. 1263-1278, 2004
[3] R.S. Gemmen, "Analysis for the effect of inverter ripple current on fuel cell operating condition," J. Fluids Eng., vol. 125, no. 3, pp. 576$585,2003$.

[4] NETL, "Fuel cell specifications for Future Energy Challenge 2001 Competition," http://www.netl.doe.gov (accessed on 2 July 2010).

[5] R.J. Wai, and Y.L. Chun, "Dual active low-frequency ripple control for clean-energy power-conditioning mechanism," IEEE Trans. Ind. Electron., vol. 58, no. 11, pp. 5172-5185, 2011

[6] D.S. Sha, Y.X. Xu, J.K. Zhang, and Y. Yan, "A current-fed hybrid dual active bridge DC-DC converter for fuel fell power conditioning system with reduced input current ripple," IEEE Trans. Ind. Electron., in press.

[7] P.M. García-Vite, et al., "A DC-DC converter with quadratic gain and input current ripple cancelation at a selectable duty cycle," Renewable Energy, vol. 101, no. 2, pp. 431-436, 2017.

[8] D.B.W. Abeywardana, B. Hredzak, and V.G. Agelidis, "An input current feedback method to mitigate the DC-side low-frequency ripple current in a single-phase boost inverter," IEEE Trans. Power Electron., vol. 31, no. 6, pp. 4594-4603, 2016.

[9] M.V. Naik and P. Samue, "Analysis of ripple current, power losses and high efficiency of DC-DC converters for fuel cell power generating systems," Renewable and Sustainable Energy Reviews, vol. 59, no. 6, pp. 1080-1088, 2016

[10] J.S. Kim, G.Y. Choe, H.S. Kang, and B.K. Lee, "Effect of load modeling on low frequency current ripple in fuel cell generation systems," J. Electrical Engineering \& Technology, vol. 5, no. 2, pp. 307-318, 2010

[11] P. Hong P, J.Q. Li, L.F. Xu, M. G. Ouyang, and C. Fang, "Modeling and simulation of parallel DC/DC converters for online AC impedance estimation of PEM fuel cell stack," Int. J. Hydrogen Energy, vol. 41, no. 4, pp. 3004-3014, 2016.

[12] P.F. Ksiazek and M. Ordonez, "Swinging bus technique for ripple current elimination in fuel cell power conversion," IEEE Trans. Power Electron., vol. 29, no. 1, pp. 170-178, 2014.

[13] Y.D. Zhan, Y.G. Guo, J.G. Zhu, and L. Li, "Performance comparison of input current ripple reduction methods in UPS applications with hybrid PEM fuel cell/supercapacitor power sources," Int. J. Electrical Power and Energy Systems, vol. 64, no. 1, pp. 96-103, 2015.

[14] Y.D. Zhan, Y.G. Guo, J.G. Zhu, and H. Wang, "Intelligent uninterruptible power supply system with backup fuel cell/battery hybrid power sources," J. of Power Sources, vol. 179, no. 2, pp. 745$753,2008$.

[15] Y.D. Zhan, H. Wang, and J.G. Zhu, "Modelling and control of hybrid UPS system with backup PEM fuel cell/battery," Int. J. Electrical Power and Energy Systems, vol. 43, no. 1, pp. 1322-1331, 2012.

[16] Y.D. Zhan, Y.G. Guo, J.G. Zhu, and L. Li, "Current short circuit implementation for performance improvement and lifetime extension of proton exchange membrane fuel cell," J. of Power Sources, vol. 270, no. 1, pp.183-192, 2014. 